\title{
Goals scored and received in 5vs4 GK game strategy are constrained by critical moment and situational variables in elite futsal
}

\section{Méndez-Domínguez, M.A. Gómez-Ruano, L.M. Rúiz-Pérez \& B. Travassos}

To cite this article: C. Méndez-Domínguez, M.A. Gómez-Ruano, L.M. Rúiz-Pérez \& B. Travassos (2019): Goals scored and received in 5vs4 GK game strategy are constrained by critical moment and situational variables in elite futsal, Journal of Sports Sciences, DOI: 10.1080/02640414.2019.1640567

To link to this article: https://doi.org/10.1080/02640414.2019.1640567

Published online: 13 Jul 2019.

Submit your article to this journal $\llbracket$

View Crossmark data ¿ 


\title{
Goals scored and received in 5vs4 GK game strategy are constrained by critical moment and situational variables in elite futsal
}

\author{
C. Méndez-Domínguez $\mathbb{D D}^{\mathrm{a}}$, M.A. Gómez-Ruano $\mathbb{D}^{\mathrm{a}}$, L.M. Rúiz-Pérez $\mathbb{D}^{\mathrm{a}}$ and B. Travassos $\mathbb{D}^{\mathrm{b}}$
}

aPhysical Activity and Sport Sciences, Technical University of Madrid, Madrid, Spain; ${ }^{b}$ CIDESD, Research Center in Sports Sciences, Health Sciences and Human Development, Department of Sport Sciences, University of Beira Interior, Covilhã, Portugal

\section{ABSTRACT}

The aim of this study was to identify the importance and meaning of goals using the goalkeeper as an outfield player in elite futsal according to critical and situational variables. The sample consisted of 11,446 actions corresponding to 1,325 matches from the $1^{\text {st }}$ division Spanish Futsal League during the seasons from 2010 to 2015. Multinomial logistic regression and classification tree multivariate models were used to identify the best predictor variables related to the likelihood of scoring goals, receiving goals, or no goals. Results from Multinomial logistic regression emphasised goals scored in balanced matches and playing with the goalkeeper as an outfield player before the last eight minutes. When the teams were drawing or losing, finished with goals received or without goals. The classification tree results identified a greater likelihood of scoring goals when the teams were winning, in balanced matches, and within the last eight minutes. Conversely, a greater likelihood of suffering goals was observed using the goalkeeper as an outfield player when the teams were losing, in unbalanced matches and in the last eight minutes. The identified trends will allow futsal coaches to recognise the most suitable situations for achieving efficacy when using the goalkeeper as an outfield player strategy.
ARTICLE HISTORY

Accepted 25 June 2019

KEYWORDS

Performance analysis; goalkeeper; criticality; situational variables (SV); classification tree analysis (CHAID)

\section{Introduction}

Futsal is usually compared to football and associated with a small-sided version of this game. However, Futsal has its own specific dynamics due to the different rules, number of players, field dimensions and balls used. For instance, the FIFA futsal regulations allow the use of the goalkeeper as an outfield player (5vs4+ GK) during the game. It means that any player may change places with the specific goalkeeper (FIFA futsal law 3the number of players -changing the goalkeeper). Usually, futsal coaches use the risky 5vs4+ GK strategy (the team plays without a goalkeeper in the goal and leaving out free space in the defensive midfield) to unbalance the numerical relations between outfield players and increase the likelihood of generating goal scoring opportunities (Corrêa, Davids, Silva, Denardi, \& Tani, 2014; Vicente-Vila \& Lago-Peñas, 2016). This game strategy is almost always used in the final moments of the match when the team is losing, as a strategic option to recover the balance on the scoreboard (Barbosa, 2011; Ganef, Pereira, De Almeida, \& Coppi, 2009; Newton-Ribeiro, 2011; Vicente-Vila, 2012; VicenteVila \& Lago-Peñas, 2016).

The observed changes on the numerical relations between outfield players promote adaptations especially in the interpersonal relations between defending players. Due to the numerical inferiority on the field, defensive players tend to be more coordinated to maintain the compactness between the ball and the goal (Travassos, Araújo, Vilar, \& McGarry, 2011). Such a strategy allows the defensive team to intercep passing actions or block shots to goal and quickly progress on the field with the attacking team unbalanced or shooting at the goal without the goalkeeper. The capacity of the defensive team to manage the numerical unbalance or the attacking team to play without a goalkeeper in the goal can be a decisive factor for defining the final outcome of futsal matches, which seems to be related to the tactical effectiveness of the defensive system to perform disarmament of the ball, and to the offensive system that ends the attack situations and then does not generate turnovers (Miloski, Pinho, Gobo, Rebouças, \& Schultz, 2014).

According to previous research, the 5vs4 + GK game strategy may cause changes on the scoreboard that can establish a final balance of goals in favor (goals scored) or against (goals received). For instance, in Brasil it was reported a similar number of goals in favor (17\%) and against (17\%) (Barbosa, 2011). However, some studies indicated a better final balance (saldo pro goleiro) of goals in favor (goal pro goleiro) than of goals against (goal contra goleiro) during international matches (Ganef et al., 2009). These findings were confirmed in later studies, where it has been revealed the highest number of goals scored $(21 \%)$ in relation to the goals received $(5 \%)$ in the men's national league (Fukuda \& Santana, 2012), as well as in the U20 women's championship (Bezerra \& Coppi, 2012) when teams are using this game strategy. Conversely, a recent study revealed that the use of the 5vs4+ GK game strategy did not cause changes in match status, and the teams that were losing and used the 5vs4+ GK game strategy lost the 
game in $93 \%$ of the cases and received more goals compared to those scored (Méndez, 2018). Despite such results, and due to the importance of this game strategy for coaches, further studies are needed to understand the really impact of this option on the efficacy and consequently on the final outcome of the match (Vicente-Vila \& Lago-Peñas, 2016).

Previous research on team sports has also analysed the effect of some Critical Moment Variables (CMV) such as match status, play time and game criticality on variations of game dynamics (Navarro, Lorenzo, Gómez, \& Sampaio, 2009; Sampaio, Lorenzo, \& Ribeiro, 2006). In Futsal, the analysis of Critical Moments (CM) revealed how match status, play time and fouls committed constrained shooting chances (Méndez, Gómez, Rúiz, \& Travassos, 2019), but also constrained coaches to adopt the 5vs4+ GK game strategy (Méndez, Gómez-Ruano, Ruiz, \& Cui, 2017). Particularly, it was observed that when a disadvantaged match status of one goal or more occurs, this game strategy was preferentially adopted (Barbosa, 2011). In addition, the 5vs4+ GK game strategy occurs almost always in the last minutes of the match as a final strategy to reduce the goal disadvantage in a short time (Ganef et al., 2009; Newton-Ribeiro, 2011). Also, the effect of some Situational Variables (SV) has been highly investigated (Gómez, LagoPeñas, \& Pollard, 2013; Lago-Ballesteros, Lago-Peñas, Rey, Martínez, \& Domínguez, 2012). For instance, in futsal the match location revealed an effect on teams' success, with a greater likelihood for home teams (Sampedro \& Prieto, 2011, 2012). Recently, a study on attacking game situations in numerical superiority with the $4 \mathrm{vs} 3+\mathrm{GK}$ and $5 \mathrm{vs} 3$ + GK game strategies also revealed a higher attack effectiveness for home teams and the great importance of the match type (Gómez, Méndez, Indaburu, \& Travassos, 2018).

However, the available literature exploring the relationship between Situational Variables (SV) and the impact generated by the $C M$ on ball possession efficacy in teams using the 5vs4+ GK game strategy is limited (Moore, Bullough, Goldsmith, \& Edmondson, 2014). Due to the main goal of the 5vs4+ GK game strategy, that is generating goal scoring opportunities without exposing the team to shots from the opposing team, such information is paramount to help coaches to improve the use of such a risky strategy, so it would be interesting that they will not think of using it as a last resource or emergency solution, rather turning it into an alternative to the symmetry game through of an adequate training from the youth categories (Ganef et al., 2009; Newton-Ribeiro, 2011). Thus, multivariate statistical models, such as multinomial logistic regression or classification tree analysis, have been suggested to be suitable for exploring and modeling data related to the control of team performance indicators (Gómez, Lorenzo, Ibañez, \& Sampaio, 2013; Gómez, Moral, \& Lago-Peñas, 2015; Maneiro, Casal, Ardá, \& Losada, 2019). Therefore, the aim of the present study was to understand how SV and CMV in futsal constrain ball possession efficacy in the 5vs4+ GK game strategy using multivariate analysis. It was hypothesised that ball possession efficacy with the 5vs4+ GK game strategy is constrained by SV and CMV.

\section{Method}

\section{Data sampling and ethical approval}

A total of 1,325 matches from the regular phase and playoffs of the 2010-2011 to the 2014-2015 Spanish men's professional futsal league matches (LNFS $1^{\text {st }}$ division) were analyzed. A sample of 11,446 5vs4+ GK game pieces were considered for the analysis. Each game piece was coded according to ball possession efficacy as: a) goal scored, b) goal received and c) no goal.

The Spanish Professional Futsal League (LNFS) granted the necessary permits to provide the images and use them for research purposes. The Ethics Committee of Research and Development activities of UPM (Technical University of Madrid) was responsible for the evaluation of ethical aspects in order that data collection and processing used in this study will not affect fundamental rights. The ethics committee confirmed that the study respects the European data protection law (General Data Protection Regulation) regarding the public data processing of team sports. Once informed of the activity described in this manuscript, it was reviewed and approved by the Ethics Committee of Research and Development activities of UPM in order to be published.

\section{Data processing}

The matches were analysed through systematic observation using the video analysis software Astrofutsal ${ }^{\oplus}$ (Méndez \& Méndez, 2005), which is being employed for notational analysis in sports research and is currently a common tool for analysing international futsal competitions (Paz-Franco, Bores-Cerezal, Barcala-Furelos, \& Mecias-Calvo, 2014). Payment licence are necessary to access their datasets, and requests should be addressed through registration at http://www.astro-sport.com. The informed consent of the company was obtained in order that this study could use their statistical reports data in research, as well as in subsequent publications, in exchange for the source of the data repository being named.

Two experienced observers (12 years of experience in the notational analysis of futsal events with the use of this tool), participated in the process of data reliability. The match between Pozo de Murcia vs Inter Movistar (Playoff final series 2014-2015) was re-analysed to check inter-observer reliability. The two observers recorded the futsal match events and then the 5vs4+ GK actions of both teams, and their records were compared using Cohen's Kappa index (k) (Robinson \& O'Donoghue, 2007), obtaining a very good agreement between both independent observers (values greater than .89) (Viera \& Garrett, 2005).

\section{Data notation}

All the variables studied are defined in the Table 1 . The efficacy of each 5vs4+ GK ball possession: goal scored (attacking team scoring a goal) goal received (defending team scoring a goal) and no goal (ball possession did not cause changes on the scoreboard) was considered as the dependent variable.

The independent variables were related to CMV and SV. The SV included: (i) match location (playing at home or away); (ii) opponent's strength, considering the 16-team ranking at the end 
Table 1. Distribution of frequencies (\%) for ball posession efficacy (no goal, goal scored, goal received) in attack with goalkeeper as an outfield player according to critical and situational variables (Contingency table: Chi-square, degrees of freedom, significance, minimum expected frequency and effect size).

\begin{tabular}{|c|c|c|c|c|c|c|c|c|c|c|c|}
\hline \multirow[b]{2}{*}{ Variables } & \multicolumn{2}{|c|}{$\begin{array}{c}\text { No Goal } \\
n=10218\end{array}$} & \multicolumn{2}{|c|}{$\begin{array}{c}\text { Goal scored } \\
n=582\end{array}$} & \multicolumn{2}{|c|}{$\begin{array}{c}\text { Gol Received } \\
n=646\end{array}$} & \multirow[b]{2}{*}{$x^{2}$} & \multirow[b]{2}{*}{ df } & \multirow[b]{2}{*}{$P$} & \multirow[b]{2}{*}{ MEF } & \multirow[b]{2}{*}{$E S$} \\
\hline & $\%$ & $n$ & $\%$ & $n$ & $\%$ & $n$ & & & & & \\
\hline \multicolumn{12}{|l|}{ Competition } \\
\hline Regular phase & 90.6 & 9259 & 92.4 & 538 & 91.5 & 591 & 2.621 & 2 & .270 & 53.80 & 0.01 \\
\hline Play off & 9.4 & 959 & 7.6 & 44 & 8.5 & 55 & - & - & - & - & - \\
\hline \multicolumn{12}{|l|}{ Match Location } \\
\hline Home & 40.4 & 4124 & 45.9 & 267 & 40.1 & 259 & 7.027 & 2 & $.030^{*}$ & 236.4 & 0.02 \\
\hline Away & 59.6 & 6094 & 54.1 & 315 & 59.9 & 387 & - & - & - & - & - \\
\hline \multicolumn{12}{|l|}{ Opponent's strength } \\
\hline Best (5v4) vs. worst & 7.8 & 795 & 12.2 & 71 & 4.6 & 30 & 45.482 & 4 & $.001^{* *}$ & 45.56 & 0.04 \\
\hline $5 \mathrm{v} 4$ between balanced & 61.0 & 6238 & 63.2 & 368 & 56.5 & 365 & - & - & - & - & - \\
\hline Worst (5v4) vs. best & 31.2 & 3185 & 24.6 & 143 & 38.9 & 251 & - & - & - & - & - \\
\hline \multicolumn{12}{|l|}{ Match type } \\
\hline Balanced & 55.4 & 5656 & 72.5 & 422 & 30.3 & 196 & 230.988 & 2 & $.001^{* *}$ & 262.9 & 0.14 \\
\hline Unbalanced & 44.6 & 4562 & 27.5 & 160 & 69.7 & 450 & - & - & - & - & - \\
\hline \multicolumn{12}{|l|}{ Play time } \\
\hline 1st half & - & 348 & - & 11 & - & 16 & - & - & - & - & - \\
\hline $0-8$ & 2.3 & 8 & 0.0 & 0 & 0.0 & 0 & 6.709 & 8 & .446 & $0.23 \dagger$ & 0.10 \\
\hline $9-16$ & 5.5 & 19 & 0.0 & 0 & 0.0 & 0 & - & - & - & - & - \\
\hline $17-24$ & 10.3 & 36 & 18.2 & 2 & 12.5 & 2 & - & - & - & - & - \\
\hline $25-32$ & 24.4 & 85 & 45.5 & 5 & 43.8 & 7 & - & - & - & - & - \\
\hline $33-40$ & 57.5 & 200 & 36.4 & 4 & 43.8 & 7 & - & - & - & - & - \\
\hline 2nd half & - & 9772 & - & 567 & - & 626 & - & - & - & - & - \\
\hline $0-8$ & 1.9 & 189 & 1.4 & 8 & 1.6 & 10 & 7.822 & 8 & .451 & 10.70 & 0.01 \\
\hline $9-16$ & 3.1 & 306 & 2.3 & 13 & 2.9 & 18 & - & - & - & - & - \\
\hline $17-24$ & 8.6 & 838 & 9.5 & 54 & 7.2 & 45 & - & - & - & - & - \\
\hline $25-32$ & 28.2 & 2753 & 29.5 & 167 & 25.9 & 162 & - & - & - & - & - \\
\hline $33-40$ & 58.2 & 5686 & 57.3 & 325 & 62.5 & 391 & - & - & - & - & - \\
\hline Extra time & - & 98 & - & 4 & - & 4 & - & - & - & - & - \\
\hline \multicolumn{12}{|l|}{ Match status } \\
\hline Losing & 91.1 & 9311 & 63.6 & 370 & 97.7 & 631 & 641.250 & 4 & $.001^{* *}$ & 10.12 & 0.16 \\
\hline Drawing & 7.6 & 781 & 24.6 & 143 & 1.7 & 11 & - & - & - & - & - \\
\hline Winning & 1.2 & 126 & 11.9 & 69 & 0.6 & 4 & - & - & - & - & - \\
\hline \multicolumn{12}{|l|}{ Fouls committed } \\
\hline 0 & 3.7 & 375 & 3.4 & 20 & 3.6 & 23 & 15.588 & 10 & .112 & 21.25 & 0.02 \\
\hline $1 \mathrm{st}$ & 11.4 & 1164 & 10.8 & 63 & 12.4 & 80 & - & - & - & - & - \\
\hline 2nd & 25.2 & 2572 & 29.6 & 172 & 24.3 & 157 & - & - & - & - & - \\
\hline $3 r d$ & 25.9 & 2648 & 23.7 & 138 & 27.1 & 175 & - & - & - & - & - \\
\hline 4 th & 16.0 & 1635 & 18.9 & 110 & 15.3 & 99 & - & - & - & - & - \\
\hline 5th & 17.9 & 1824 & 13.6 & 79 & 17.3 & 112 & - & - & - & - & - \\
\hline \multicolumn{12}{|l|}{ Criticality } \\
\hline High (12-15) & 73.0 & 7460 & 54.6 & 318 & 73.8 & 477 & 98.599 & 4 & $.001^{* *}$ & 19.63 & 0.06 \\
\hline Medium (9-11) & 23.6 & 2412 & 41.2 & 240 & 23.7 & 153 & - & - & - & - & - \\
\hline Low (4-8) & 3.4 & 346 & 4.1 & 24 & 2.5 & 16 & - & - & - & - & - \\
\hline
\end{tabular}

of the regular season, measured as the end-of-season ranking differences between the two teams (Rank team A - Rank team B). The $k$-means cluster analysis established three different groups (1: best ranked teams vs. worst ranked teams; 2: balanced level of opposition: best teams vs. best teams and worst teams vs. worst teams; 3: worst ranked teams vs. best ranked teams); (iii) the competition phase: regular phase or playoff (where only the first eight ranked teams participate); and (iv) match type: balanced (with a difference of up to two goals) or unbalanced (with a more than two goal difference).

The CMV included: (v) play time, which was defined in five sub-periods of eight minutes in each half time. The $k$-means cluster analysis was established with 5 levels, so that it could correspond with the likert scale of 5 degrees that measures the criticality of the play time, finally establishing groupings with average values of 8-minute for each level $(0-8,9-16$, $17-24,25-32,33-40$, and extra time in case needed in playoffs); (vi) the match status (winning, drawing or losing); (vii) fouls committed, the number of the team's accumulated fouls $(0,1 \mathrm{st}, 2 \mathrm{nd}, 3 \mathrm{rd}, 4 \mathrm{th}$ or 5 th); and (viii) the critical level of the match, considering the three previous variables, where the highest values represent the appearance of unfavourable CM (Ferreira \& Volossovitch, 2013; Ferreira, Volossovitch, \& Sampaio, 2014) for one of the teams. The $k$-means cluster analysis established three different critical levels (low: cumulative values between 4 and 8; medium: values between 9 and 11 , and high: values between 12 and 15).

\section{Statistical analysis}

Firstly, a descriptive and inferential analysis was performed using Crosstab Commands. Pearson's Chi-square test was used to analyse the relationships between ball possession efficacy with SV and CMV. The effect sizes (ES) were calculated using Cramer's $V$ test and their interpretation were based on the following criteria: $0.10=$ small effect, $0.30=$ medium effect and $0.50=$ large effect (Volker, 2006).

Secondly, a multinomial logistic regression model was used to assess the influence exerted by the interaction of the independent variables (SV and CMV) on ball possession 
efficacy with 5vs4+ GK (Gómez et al., 2015; Vicente-Vila \& Lago-Peñas, 2016). In the logistic regression model, ball possession efficacy was included as a polytomous dependent variable, depending on whether the 5vs4+ GK ended in a goal scored, goal received, or no goal. In addition, the reference category of the dependent variable was established, so that all the categories were compared to each other (1: attacks without goals compared to attacks with goals received; 2: attacks with goals scored compared to attacks with goals received, and 3: attacks with goals scored compared to attacks without goals) and always in relation to the independent variables included in the study. For each variable the odds ratios (OR) and their $95 \%$ confidence intervals $(\mathrm{Cl})$ were determined. The significance level was established at $P<0.05$.

Thirdly, the exhaustive chi-squared automatic interaction detection (CHAID) classification tree analysis was used to split the sample into nodes (subgroups) in order to identify the best predictors (independent variables) of ball possession efficacy with 5vs4+ GK (Gómez et al., 2015).The statistical model specifications were: (i) the significance level was set at $P<0.05$; (ii) Pearson's Chi-square was used; (iii) the maximum number of iterations were 100-50; (iv) the minimum change in expected cell frequencies was $0.001 ;(v)$ the Bonferroni method was used to obtain the significance values of adjustment; (vi) cross-validation was carried out and, for each subsample, one tree was built with the remaining cases (90\%); (vii) the tree had a three level maximum, and (viii) the misclassification risk was calculated as a measure of the model reliability (Schnell, Mayer, Diehl, Zipfel, \& Thiel, 2014). Statistical analyses were performed using IBM SPSS for Windows statistics, version 22.0 (Armonk, NY: IBM. Corp.).

\section{Results}

The distribution of frequencies for ball posession efficacy (goal scored, goal received, no goal) from the studied variables is shown in Table 1 (percentage and case numbers). A significant relationship was found between the greater likelihood of scoring goals and the 5vs4+ GK game strategy by local teams, in best ranked teams vs. worst ranked teams, and balanced matches. Conversely, but as expected, a significant relationship was found between the greater likelihood of receiving goals and the 5vs4+ GK game strategy when the team was losing, and at a high criticality level.

Results from the multinomial logistic regression analysis (Table 2, III and IV) identify ball possession efficacy with the 5vs4+ GK game strategy concerning the independent variables. The results showed that the model was statistically significant $\left(X^{2}=669,232 ; P=.001\right)$, correctly classifiying $89.3 \%$ of the cases. Table 2 compares the attacks without goals against attacks with goals received and concerning the independent variables. The model showed a greater likelihood of there being no changes on the scoreboard when the 5vs4+ GK game strategy was used during the first half $(O R=3.847)$, and during the first four play time intervals, namely between $0-8 \mathrm{~min}(\mathrm{OR}=2.211)$, 9-16 $\min (O R=2.016), 17-24 \min (O R=1.829)$, and

Table 2. Effects of the independent variables on ball possession efficacy in attack with goalkeeper as an outfield player, comparing attacks without goals with the ones with goals received.

\begin{tabular}{|c|c|c|c|c|c|c|c|c|c|}
\hline \multirow{2}{*}{$\begin{array}{l}\text { Ball possession } \\
\text { performance }^{\mathrm{a}}\end{array}$} & \multirow[b]{2}{*}{ Variables } & \multirow[b]{2}{*}{$\mathrm{B}$} & \multirow[b]{2}{*}{ S.E. } & \multirow[b]{2}{*}{ Wald } & \multirow[b]{2}{*}{ df } & \multirow[b]{2}{*}{$P$} & \multirow[b]{2}{*}{$\mathrm{OR}$} & \multicolumn{2}{|c|}{ OR (95\% C.I.) } \\
\hline & & & & & & & & Lower & Upper \\
\hline \multirow[t]{27}{*}{ Attack without a goal } & Constant & 1760 & .792 & 4.938 & 1 & .026 & - & - & - \\
\hline & Regular Phase & -.162 & .154 & 1.116 & 1 & .291 & .850 & .629 & 1.149 \\
\hline & Play Off & 0 & - & - & 0 & - & - & - & - \\
\hline & Home & -.089 & .085 & 1.112 & 1 & .292 & .915 & .785 & 1.080 \\
\hline & Away & 0 & - & - & 0 & - & - & - & - \\
\hline & Best (5v4) vs. worst & .194 & .205 & .895 & 1 & .344 & 1.214 & .812 & 1.813 \\
\hline & $5 \mathrm{v} 4$ between balanced & .126 & .088 & 2.048 & 1 & .152 & 1.135 & .954 & 1.349 \\
\hline & Worst (5v4) vs. best & 0 & - & - & 0 & - & - & - & - \\
\hline & Balanced match & 1.045 & .092 & 128.009 & 1 & $.001^{* *}$ & 2.844 & 2.373 & 3.409 \\
\hline & Unbalanced match & 0 & - & - & 0 & - & - & - & - \\
\hline & 1st half & 1.347 & .649 & 4.305 & 1 & $.038^{*}$ & 3.847 & 1.078 & 13.738 \\
\hline & 2nd half & .853 & .595 & 2.056 & 1 & .152 & 2.347 & .731 & 7.530 \\
\hline & Extra time & 0 & - & - & 0 & - & - & - & - \\
\hline & $0-8 \mathrm{~min}$ & .794 & .358 & 4.902 & 1 & $.027^{*}$ & 2.211 & 1.095 & 4.465 \\
\hline & $9-16 \min$ & .701 & .268 & 6.842 & 1 & $.009^{* *}$ & 2.016 & 1.192 & 3.409 \\
\hline & $17-24 \min$ & .604 & .168 & 12.866 & 1 & $.001^{* *}$ & 1.829 & 1.315 & 2.544 \\
\hline & $25-32 \mathrm{~min}$ & .367 & .100 & 13.490 & 1 & $.001^{* *}$ & 1.444 & 1.187 & 1.757 \\
\hline & $33-40 \mathrm{~min}$ & 0 & - & - & 0 & - & - & - & - \\
\hline & Losing & -.541 & .517 & 1.095 & 1 & .295 & .582 & .211 & 1.604 \\
\hline & Drawing & .609 & .596 & 1.045 & 1 & .307 & 1.839 & .572 & 5.916 \\
\hline & Winning & 0 & - & - & 0 & - & - & - & - \\
\hline & 0 & -.309 & .282 & 1.194 & 1 & .275 & .734 & .422 & 1.278 \\
\hline & 1st foul & -.175 & .164 & 1.128 & 1 & .288 & .840 & .608 & 1.159 \\
\hline & 2nd foul & -.036 & .133 & .073 & 1 & .788 & .965 & .744 & 1.251 \\
\hline & 3rd foul & -.076 & .127 & .356 & 1 & .551 & .927 & .722 & 1.189 \\
\hline & 4 th foul & .013 & .144 & .009 & 1 & .925 & 1.014 & .764 & 1.345 \\
\hline & 5 th foul & 0 & - & - & 0 & - & - & - & - \\
\hline
\end{tabular}

Note: S.E: = Standard error; $\mathrm{Cl}=$ Confidence intervals; a) the reference category of the dependent variable that is compared: Goal received; b) the redundant category of the independent variable that is compared when $\mathrm{OR}=1$.

${ }^{*} P<.05 . ;{ }^{* *} P<.01$. 
Table 3. Effects of the independent variables on ball possession efficacy in attack with goalkeeper as an outfield player, comparing attacks with goals scored with the ones with goals received.

\begin{tabular}{|c|c|c|c|c|c|c|c|c|c|}
\hline \multirow{2}{*}{$\begin{array}{l}\text { Ball possession } \\
\text { performance }^{a}\end{array}$} & \multirow[b]{2}{*}{ Variables } & \multirow[b]{2}{*}{ B } & \multirow[b]{2}{*}{ S.E. } & \multirow[b]{2}{*}{ Wald } & \multirow[b]{2}{*}{ df } & \multirow[b]{2}{*}{$P$} & \multirow[b]{2}{*}{ OR } & \multicolumn{2}{|c|}{ OR (95\% C.I.) } \\
\hline & & & & & & & & Lower & Upper \\
\hline \multirow[t]{27}{*}{ Attack with Goal Scored } & Constant & .121 & 1.022 & .014 & 1 & .906 & - & - & - \\
\hline & Regular Phase & -.201 & .227 & .785 & 1 & .376 & .818 & .524 & 1.227 \\
\hline & Play Off & 0 & - & - & 0 & - & - & - & - \\
\hline & Home & -.049 & .121 & .165 & 1 & .685 & .952 & .751 & 1.207 \\
\hline & Away & 0 & - & - & 0 & - & - & - & - \\
\hline & Best (5v4) vs. worst & .033 & .259 & .016 & 1 & .898 & 1.034 & .622 & 1.717 \\
\hline & $5 v 4$ betw balanced & .159 & .136 & 1.374 & 1 & .241 & 1.172 & .899 & 1.529 \\
\hline & Worst (5v4) vs. best & 0 & - & - & 0 & - & - & - & - \\
\hline & Balanced match & 1.565 & .137 & 130.944 & 1 & $.001^{* *}$ & 4.782 & 3.658 & 6.251 \\
\hline & Unbalanced match & 0 & - & - & 0 & - & - & - & - \\
\hline & 1st half & 1.311 & .958 & 1.871 & 1 & .171 & 3.709 & .567 & 24.257 \\
\hline & 2nd half & 1.650 & .872 & 3.581 & 1 & .058 & 5.206 & .943 & 28.743 \\
\hline & Extra time & 0 & - & - & 0 & - & - & - & - \\
\hline & $0-8 \mathrm{~min}$ & .809 & .536 & 2.272 & 1 & .132 & 2.245 & .784 & 6.424 \\
\hline & $9-16 \min$ & .413 & .405 & 1.045 & 1 & .307 & 1.512 & .684 & 3.341 \\
\hline & $17-24 \mathrm{~min}$ & .940 & .232 & 16.456 & 1 & $.001^{* *}$ & 2.560 & 1.626 & 4.033 \\
\hline & $25-32 \mathrm{~min}$ & .589 & .142 & 17.159 & 1 & $.001^{* *}$ & 1.803 & 1.364 & 2.382 \\
\hline & $33-40 \mathrm{~min}$ & 0 & - & - & 0 & - & - & - & - \\
\hline & Losing & -3.161 & .530 & 35.565 & 1 & $.001^{* *}$ & .042 & .015 & .120 \\
\hline & Drawing & -.564 & .609 & .857 & 1 & .354 & .569 & .173 & 1.877 \\
\hline & Winning & 0 & - & - & 0 & - & - & - & - \\
\hline & 0 & -.031 & .409 & .006 & 1 & .940 & .970 & .435 & 2.161 \\
\hline & 1st foul & .314 & .247 & 1.620 & 1 & .203 & 1.369 & .844 & 2.220 \\
\hline & 2nd foul & .472 & .196 & 5.783 & 1 & $.016^{*}$ & 1.602 & 1.091 & 2.353 \\
\hline & 3rd foul & .207 & .194 & 1.139 & 1 & .286 & 1.230 & .841 & 1.799 \\
\hline & 4th foul & .553 & .210 & 6.943 & 1 & $.008^{* *}$ & 1.739 & 1.152 & 2.624 \\
\hline & 5 th foul & 0 & - & - & 0 & - & - & - & - \\
\hline
\end{tabular}

Note: S.E: = Standard error; $\mathrm{Cl}=$ Confidence intervals; a) the reference category of the dependent variable that is compared: Goal received; b) the redundant category of the independent variable that is compared when $\mathrm{OR}=1$.

$* P<.05$; ${ }^{* *} P<.01$.

25-32 $\min (O R=1.444)$, in the case of balanced matches $(\mathrm{OR}=2.844)$.

Table 3 compares the attacks with goals scored against attacks with goals received and concerning the independent variables. The model showed a greater likelihood of scoring goals with the 5vs4+ GK game strategy in balanced matches $(O R=4.782)$, in play time intervals furthest from the end of the match, particularly between 17 to $24 \mathrm{~min}(\mathrm{OR}=2.560)$ and 25 to $32 \mathrm{~min}(\mathrm{OR}=1.803)$, and before the arrival of the 5th foul, particularly with the 2nd accumulated foul ( $O R=1.602)$ as well as the 4th one $(\mathrm{OR}=1.739)$. Conversely to what would happen with a favorable scoreboard, when the 5vs4+ GK game strategy was used by a losing team there was a lower likelihood of scoring goals $(\mathrm{OR}=.042)$, increasing the probability of receiving goals.

Table 4 compares the attacks with goals scored against attack without goals and concerning the independent variables. The model showed a greater likelihood of scoring goals with the 5vs4+ GK game strategy in balanced matches $(O R=1.681)$, in play time intervals furthest from the end of the match, specifically between the 17 to $24 \mathrm{~min}(\mathrm{OR}=1.400)$ and 25 to $32 \mathrm{~min}(\mathrm{OR}=1.248)$, and before the arrival of the 5 th foul, particularly with the 1 st foul $(O R=1.630)$, 2nd foul $(O R=1.661)$ as well as the 4th one $(O R=1.715)$. Conversely to what would happen with a favorable scoreboard, when the 5vs4+ GK game strategy was used in a drawn match there was a lower likelihood of scoring goals $(\mathrm{OR}=.309)$, which became a greater disadvantage if the 5vs4+ GK game strategy was used by the losing team (OR $=.073)$, increasing the probability of attacks without goals.

Thirdly, the exhaustive CHAID classification tree shows three significantly influenced factors on ball possession efficacy of the 5vs4+ GK game strategy (tree-stage three). Those factors led to 16 nodes (10 final nodes) of contrasting groups of ball possession efficacy; mainly established by match status (level 1), match type (level 2), and play time interval (level 3). Figure 1 shows the categories for the dependent variable (goal scored, goal received, no goal) and also the 16 nodes defined by the classification tree. The predictive power of the classification tree model explained $89.4 \%$ of total variance after cross-validation analysis, reaching a precision of $99.7 \%$ in cases of no goal, of $7.9 \%$ in cases of goals scored and of $1 \%$ in cases of goals received. The unbalanced precision value of the dependent variables was due to the large number of cases without a goal over the total.

At level 1 the root node is split by the match status at the moment the 5vs4+ GK is used, achieving greater efficacy with a favorable scoreboard (winning) (node 3: $34.7 \%$ of attacks with goals scored; $63.3 \%$ of attacks without goals; $2 \%$ of attacks with goals received), and less efficacy with an unfavorable scoreboard (losing) (node 1: 3.6\% of attacks with goals scored; $90.3 \%$ of attacks without goals; $6.1 \%$ of attacks with goals received). At level 2 it showed the importance of match type. Ball possession efficacy of the 5vs4+ GK game strategy was higher in those balanced matches when winning (node 9: 
Table 4. Effects of the independent variables on ball possession efficacy in attack with goalkeeper as an outfield player, comparing the attacks with goals scored with the ones without goals.

\begin{tabular}{|c|c|c|c|c|c|c|c|c|c|}
\hline \multirow{2}{*}{$\begin{array}{l}\text { Ball possession } \\
\text { performance }^{a}\end{array}$} & \multirow[b]{2}{*}{ Variables } & \multirow[b]{2}{*}{$\mathrm{B}$} & \multirow[b]{2}{*}{ S.E. } & \multirow[b]{2}{*}{ Wald } & \multirow[b]{2}{*}{ df } & \multirow[b]{2}{*}{$P$} & \multirow[b]{2}{*}{ OR } & \multicolumn{2}{|c|}{ OR (95\% C.I.) } \\
\hline & & & & & & & & Lower & Upper \\
\hline \multirow[t]{27}{*}{ Attack with Goal Scored } & Constant & -1.639 & .676 & 5.877 & 1 & .015 & - & - & - \\
\hline & Regular Phase & -.039 & .174 & .051 & 1 & .822 & .962 & .684 & 1.352 \\
\hline & Play Off & 0 & - & - & 0 & - & - & - & - \\
\hline & Home & .040 & .091 & .194 & 1 & .659 & 1.041 & .871 & 1.243 \\
\hline & Away & 0 & - & - & 0 & - & - & - & - \\
\hline & Best (5v4) vs. worst & -.161 & .166 & .934 & 1 & .334 & .852 & .615 & 1.180 \\
\hline & $5 v 4$ betw balanced & .033 & .107 & .093 & 1 & .761 & 1.033 & .838 & 1.274 \\
\hline & Worst (5v4) vs. best & 0 & - & - & 0 & - & - & - & - \\
\hline & Balanced match & .519 & .105 & 24.558 & 1 & $.001^{* *}$ & 1.681 & 1.369 & 2.065 \\
\hline & Unbalanced match & 0 & - & - & 0 & - & - & - & - \\
\hline & 1st half & -.037 & .722 & .003 & 1 & .959 & .964 & .234 & 3.968 \\
\hline & 2nd half & .797 & 654 & 1.486 & 1 & .223 & 2.218 & .616 & 7.988 \\
\hline & Extra time & 0 & - & - & 0 & - & - & - & - \\
\hline & $0-8 \min$ & .015 & .413 & .001 & 1 & .971 & 1.015 & .452 & 2.280 \\
\hline & $9-16 \min$ & -.288 & .312 & .848 & 1 & .357 & .750 & .407 & 1.384 \\
\hline & $17-24 \mathrm{~min}$ & .336 & .167 & 4.068 & 1 & $.044^{*}$ & 1.400 & 1.010 & 1.941 \\
\hline & $25-32 \mathrm{~min}$ & .222 & .105 & 4.429 & 1 & $.035^{*}$ & 1.248 & 1.015 & 1.535 \\
\hline & $33-40 \mathrm{~min}$ & 0 & - & - & 0 & - & - & - & - \\
\hline & Losing & -2.620 & .170 & 237.280 & 1 & $.001^{* *}$ & .073 & .052 & .102 \\
\hline & Drawing & -1.173 & .182 & 41.464 & 1 & $.001^{* *}$ & .309 & .216 & .442 \\
\hline & Winning & 0 & - & - & 0 & - & - & - & - \\
\hline & 0 & .278 & .307 & .818 & 1 & .366 & 1.320 & .723 & 2.411 \\
\hline & 1st foul & .489 & .191 & 6.564 & 1 & $.010^{* *}$ & 1.630 & 1.122 & 2.369 \\
\hline & 2nd foul & .507 & .149 & 11.524 & 1 & $.001^{* *}$ & 1.661 & 1.239 & 2.226 \\
\hline & 3rd foul & .283 & .151 & 3.510 & 1 & .061 & 1.327 & .987 & 1.784 \\
\hline & 4th foul & .540 & .158 & 11.660 & 1 & $.001^{* *}$ & 1.715 & 1.258 & 2.338 \\
\hline & 5th foul & 0 & - & - & 0 & - & - & - & - \\
\hline
\end{tabular}

Note: S.E: = Standard error; $\mathrm{Cl}=$ Confidence intervals; a) the reference category of the dependent variable that is compared: No goal; b) the redundant category of the independent variable that is compared when $\mathrm{OR}=1$.

${ }^{*} P<.05 . ;{ }^{* *} P<.01$.

$42.7 \%$ of attacks with goals scored; $54.5 \%$ of attacks without goals; and $2.8 \%$ of attacks with goals received); but it conversely decreased when the strategy was used in unbalanced matches when losing (node 4: $2.9 \%$ of attacks with goals scored; $88.2 \%$ of attacks without goals; $8.9 \%$ of attacks with goals received). At level 3 , the tree identified significant differences with the predictor variables when the play time interval was included. Thus, when winning matches that were already balanced (node 9), the likelihood of scoring goals with the $5 \mathrm{vs} 4+$ GK game strategy increased in the final eight minutes of the match (node 16: $57.5 \%$ of goals scored) compared to the others (node 15: $23.8 \%$ of goals scored). Similarly, the likelihood of receiving goals was greater in the final eight minutes of the match (node 11: 10.7\%) compared to the others (node 10: $7.2 \%$ of goals received), particularly when losing matches that were already unbalanced (node 4).

\section{Discussion and conclusion}

The aim of this study was to explore how CMV and SV constrain ball possession efficacy (goal scored, goal received and no goal) of the 5vs4+ GK game strategy for future predictions about its use. Results from research in futsal should lead coaches to greater knowledge of variables that constrain the use of the 5vs4+ GK strategy and its risk in different matches and at different moments of the game. In general, the results revealed an equal proportion between the goals scored ( $n=582,5.1 \%$ ) and the goals received $(n=646,5.6 \%)$ using the 5vs4+ GK game strategy. However, there was a strong constraint of the SV match type and a general constraint of
CMV on ball possession efficacy. Overall, the greater likelihood of scoring goals was achieved in the regular phase, playing at home, in balanced games, by the best ranked teams, before the last eigth minutes of the match, with a favorable match status (winning), and a variable number of accumulated fouls. Conversely, the likelihood of receiving goals corresponded to the regular phase, playing away, in unbalanced games, by the worst ranked teams, in the last eight minutes of the match, when losing, with a variable number of accumulated fouls, but always at a high criticality level.

The analysis of SV revealed the strongly constraint of match type on the ball possession efficacy. The logistic regression results showed that balanced matches had advantages regarding ball possession efficacy. Particularly a 4.78 times greater likelihood of scoring goals than receiving goals, a 2.84 times greater likelihood of not scoring than receiving goals, and a 1.68 times greater likelihood of scoring goals than not scoring, compared to unbalanced matches. Likewise, the classification tree found the significant effect of the match type starting from match status, and showed the greater efficacy in balanced compared with unbalanced matches. As match status worsened there was a progressive decrease in efficacy, which can be interpreted as a greater difficulty in scoring goals, but also a greater ease in receiving goals. For instance, in balanced games it went from $42.7 \%$ of attacks with goals scored when winning to $4.2 \%$ when losing; while in unbalanced games it went from $14.3 \%$ of attacks with goals scored when winning to $2.9 \%$ when losing, which also had a negative impact on an increase in the goals received (8.9\%). Match type is recognised as a discriminator 
of the main performance indicators, and its influence has been investigated to contextualize the factors linked with victory or defeat (Csataljay, O'Donoghue, Hughes, \& Dancs, 2009). Besides, the analysis showed an unexpected noninfluence of match location and opponent's strength, which can be explained by the fact that it is usual that the teams' strategy and their success level are affected by environmental conditions and by the opponent's assertive behaviors (Gómez, DelaSerna, Lupo, \& Sampaio, 2014), which can lead to the positive effect of the playing at home advantage being nullified by playing against balanced or stronger teams (Sampedro \& Prieto, 2011).

The multivariate analysis established the strongly constraint of CMV on the 5vs4+ GK game strategy, particularly revealing that match status strongly influences ball possession efficacy when using 5vs4+ GK. The findings from the logistic regression model revealed that when the teams were losing the likelihood of scoring goals was lower. Also, as match status worsened there was less likelihood of the attacking team scoring goals. Consistently with the previous results, the classification tree revealed that the greatest efficacy of the 5vs4+ GK game strategy was achieved when the attacking team was winning $(34.7 \%$ of attacks with goals scored, $63.3 \%$ of attacks without goals, $2 \%$ of attacks with goals received), while the least efficacy was revealed when the attacking team was losing (3.6\% of attacks with goals scored, $90.3 \%$ of attacks without goals, and $6.1 \%$ of attacks with goals received). Similarly, in a recent study from the UEFA futsal Euro 2016, it was found that the national teams that were losing and at the end were defeated scored more goals with the 5vs4 + GK strategy, but they also received more goals compared to the teams that were winning and at the end won (Göral, 2018). And another recently published study revealed that the 5vs4+ GK strategy was the most powerful match variable for discriminating losing teams, and confirmed again that the losing teams used the 5vs4+ GK strategy much more than the winning teams (Mendez, Gonçalves, Santos, Ribeiro, \& Travassos, 2019). This fact could be explained by the need to achieve a balanced scoreboard in the teams that were losing and used this strategy, and by the lower frequency of use in the teams that were winning. However, the unexpected nonsignificant influence of match status on the ball possession efficacy (Gómez et al., 2015; Vicente-Vila \& Lago-Peñas, 2016) could be justified by the fact that futsal teams losing by a recoverable difference (up to 2 goals) do not take risks playing with the 5vs4+ GK strategy, mortgaging a possible increase in offensive efficacy, or also as Lago-Peñas (2009) pointed out that critical variables would have unique effects on individual players, teams and playing styles.

Furthermore, multinomial logistic regression found a strong constraint between play time intervals and ball possession efficacy. As the end of match time approached there was a negative trend in 5vs4+ GK efficacy. Thus, the play time intervals between the 17-24 $\mathrm{min}$ and 25-32 $\mathrm{min}$, had the advantage of a 2.56 and 1.80 times greater likelihood of scoring goals than receiving goals, and the advantage of a 1.40 and 1.25 times greater likelihood of scoring goals than there being no goals in attack with 5vs4+ GK, compared to the final play time interval (33-40 min). All of which seems to point to the fact that ball possession efficacy faded near the final minutes, which would be consistent with the greatest difficulty in achieving efficacy when a CM occurs, and agrees with the criticality attributed to these final minutes by the scientific community (Ferreira, 2013; Ferreira \& Volossovitch, 2013; Ferreira et al., 2014; Navarro, Gómez, Lorenzo, \& Jiménez, 2013; Sampaio et al., 2006). Also, the results of the classification tree coincide in pointing out the final minutes of the match as those with the worst efficacy with 5vs4+ GK (92.8\% of attacks without goals), but also aggravating the likelihood that it would end in goals received ( $n=256,10.7 \%$ ), which can be explained by having been used in games that were unbalanced when losing. However, the tree also showed a greater likelihood of scoring goals within the final play time interval (33-40min) ( $n=46$, $57.5 \%$ ) compared to the others ( $n=15,23.8 \%$ ). This fact is striking because the approach to the end of a match is a difficult moment, an aspect which should be added the impact generated by the presence of a risk strategy that could decrease the efficacy, finding unexpectedly that was better, which can be explained because the strategy was used in matches that were balanced when winning (see Figure 1). This seems to agree with a previous study that revealed the importance of play time intervals close to the end of the match to establish the occurrence of this strategy with a better balance of goals in favor (saldo pro goleiro) (Ganef et al., 2009; Newton-Ribeiro, 2011). All of this is consistent with most of the studies found in the futsal field, where the occurrence of the $5 v s 4+$ GK strategy may lead to the appearance of goals (scored or received) in those final minutes, revealing that the last 10 minute period showed a higher frequency of goals and higher averages compared to the three initial play time intervals (Abdel-Hakim, 2014; Fukuda \& Santana, 2012; Poffo \& Lima, 2012; Siqueira, Da-Silva, Aragonez, Damico, \& Crescente, 2016).

Finally, fouls committed also constrain ball possession efficacy. Results from the logistic regression model showed that the arrival of the 2nd and 4th foul were linked with the probability that an attack with 5vs4+ GK ended in a goal scored and not in a goal received or no goal, compared to the 5 th foul. The trend suggests that it is better attacking with 5vs4+ GK before the 5th cumulative foul, where the likelihood of suffering goals increased. The 5 th accumulated foul or its proximity, and its possible consequences of a penalty free kick from the second penalty mark at $10 \mathrm{~m}$ (FIFA futsal law 13- Free Kicks), usually appears in the final moments of the match and the scoreboard at a disadvantage for the team that attacks with 5vs4+ GK, hence the presented findings may suggest that the lower efficacy coincides with the occurrence of a CM, and this could hinder the goal scoring chances, an aspect which has been argued in other sports (Sampaio et al., 2006). However, although the allowed limit constrains the game and team efficacy, the number of fouls committed was not significant to decide the winner and did not interfere in the futsal match outcome (Pereira-Guimarães, Neves, Rodrigues, \& Coppi, 2010).

In conclusion, the 5vs4+ GK game strategy is gaining increasing importance due to the fact that both the attacking and defending teams, have a high likelihood of achieveing advantages on the scoreboard. Further research should take into 
BALL POSSESSION EFFICACY

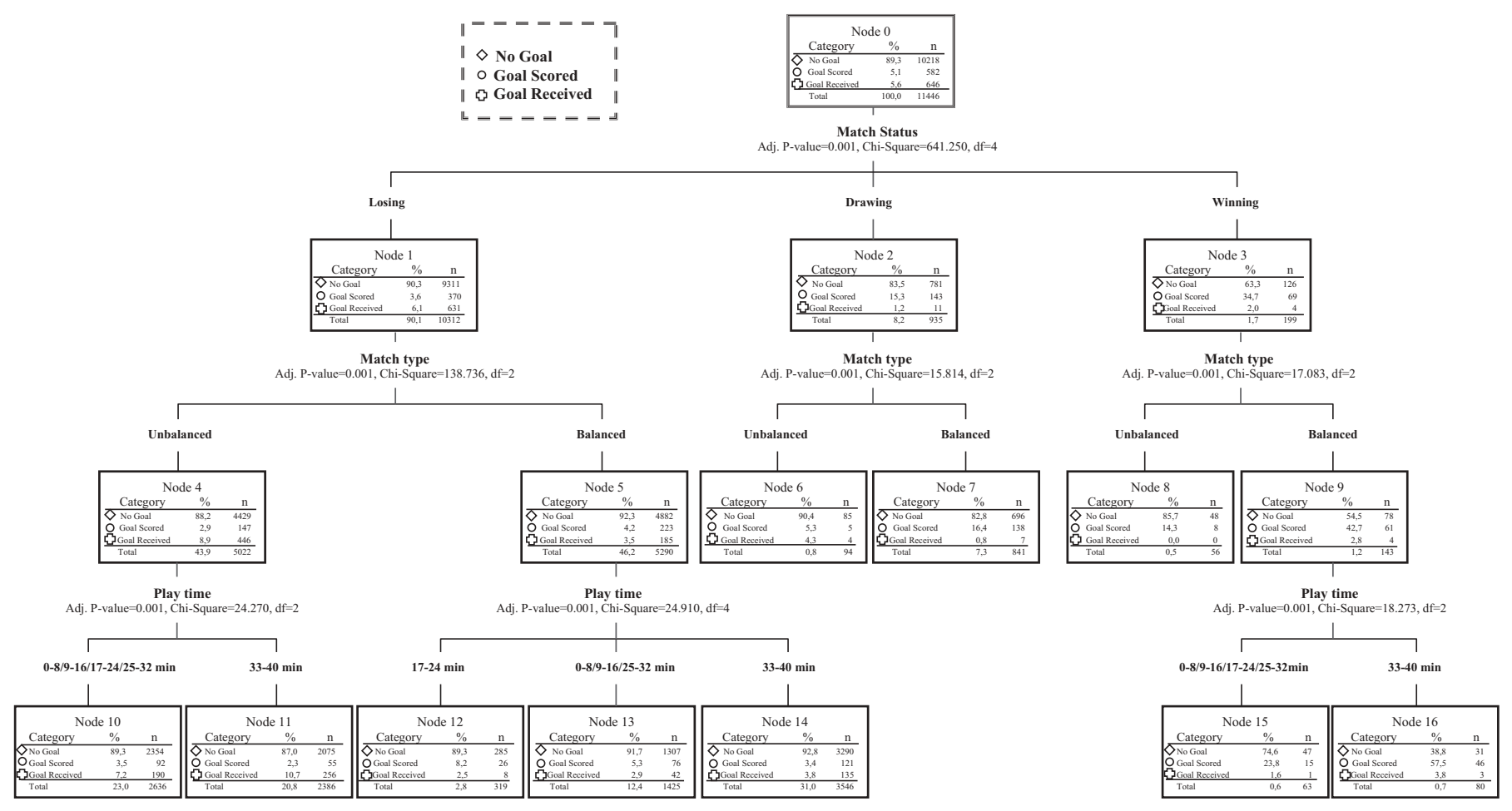

Figure 1. Classification tree analysis of ball possession efficacy.

account the different match status of each team before using this strategy, to measure its profitability, because it is not the same to use it when a team goes from winning to losing, than when it goes from drawing to losing, or when it goes from losing to winning, which could bring unknown data about the players' behavior. Also, a more appropriate diagnosis is lacking for coaches using this strategy to minimize the risks of receiving goals and to optimize the key moments of its use, which can be with $\mathrm{CM}$ anticipation, but also using the 5vs4+ GK as a possible advantage granted by the game rules. It is currently being used by the best teams in a numerical inferiority situation by dismissal, and also by the weakest teams, not so much to create goal scoring opportunities as to speculate with ball possession, which can give new data on efficacy.

\section{Practical implications and limitations}

The identified trends are of great relevance from the coach's point of view where the numerical superiority/inferiority game context directly impacts the team's performance. Accordingly, from a practical application point of view, the information obtained may change the coach's game strategy so as not to use this strategical option as a last resort tactic. For that, there is a need for coaches to change their perspective about 5vs4+ GK and incorporate it in the design of practice tasks as a usual game scenario, that can be used at any moment of the game as a dynamic game situation (3vs2., 4vs3 ... up to 5vs4) (Ganef et al., 2009; Newton-
Ribeiro, 2011). Also such results can help them identify the most appropriate moments for its application. Although it is not usual, the team that is not losing may use the risk strategy before having to overcome an adverse scoreboard, when the players are still not exposed to a CM, which would facilitate the aim of breaking a negative inertia of ball possession and goal chances by the opposing team, in order to reach the desired advantage.

The present study has some limitations that need to be addressed in future studies, one of them may be related to how to make the data analysis even more robust. It could be interesting the possibility of using survival models or statistical analyses that consider the data time dimension (random forest or T-patterns), which are particularly relevant for the analysis of the goals' achievement patterns, and the factors that can influence the probability of scoring a goal with this strategy.

\section{Disclosure statement}

No potential conflict of interest was reported by the authors.

\section{ORCID}

C. Méndez-Domínguez (ID) http://orcid.org/0000-0003-1662-2448 M.A. Gómez-Ruano (iD http://orcid.org/0000-0002-9585-3158 L.M. Rúiz-Pérez (iD) http://orcid.org/0000-0002-9678-5986 B. Travassos (ID http://orcid.org/0000-0002-2165-2687 


\section{References}

Abdel-Hakim, H. (2014). Quantitative analysis of performance indicators of goals scored in the futsal World Cup Thailand 2012. Pamukkale Journal of Sport Sciences, 5(1), 113-127.

Barbosa, A. (2011). Variação tática de goleiro linha não altera o resultado das partidas de futsal na Taça São Paulo 2009. RBFF-Revista Brasileira De Futsal E Futebol, 3(8), 101-107.

Bezerra, R., \& Coppi, A. (2012). Análise dos gols da VI Taça Brasil de Clubes 2010 na categoria sub-20 feminino. RBFF-Revista Brasileira De Futsal E Futebol, 4 (11), 47-54.

Corrêa, U., Davids, K., Silva, S., Denardi, R., \& Tani, G. (2014). The influence of a goalkeeper as an outfield player on defensive subsystems in futsal. Advances in Physical Education, 4(2), 84-92. doi:10.4236/ape.2014.42012

Csataljay, G., O'Donoghue, P., Hughes, M., \& Dancs, H. (2009). Performance indicators that distinguish winning and losing teams in basketball. International Journal of Performance Analysis in Sport, 9(1), 60-66. doi:10.1080/24748668.2009.11868464

Ferreira, A. (2013). From game momentum to criticality of game situations. In T. McGarry, P. O'Donoghue, \& J. Sampaio (Eds.), The Routledge handbook of sports performance analysis (pp. 270-282). London: Routledge International Handbooks.

Ferreira, A., \& Volossovitch, A. (2013). Criticalidad e momentos críticos nos jogos desportivos: Una revição teórica. In A. Volossovitch \& A. Ferreira (Eds.), Fundamentos e aplicações em análise do jogo ( $1^{\mathrm{a}}$ ed., pp. 35-60). Lisbon: Edições FMH.

Ferreira, A., Volossovitch, A., \& Sampaio, J. (2014). Towards the game critical moments in basketball: A grounded theory approach. International Journal of Performance Analysis in Sport, 14(2), 428-442. doi:10.1080/ 24748668.2014.11868732

Fukuda, J., \& Santana, W. (2012). Análises dos gols em jogos da Liga Futsal 2011. RBFF-Revista Brasileira De Futsal E Futebol, 4(11), 62-66.

Ganef, E., Pereira, F., De Almeida, E., \& Coppi, A. (2009). Influência do goleiro-linha no resultado do jogo de futsal. RBFF-Revista Brasileira De Futsal E Futebol, 1(3), 186-192.

Gómez, M., DelaSerna, A., Lupo, C., \& Sampaio, J. (2014). Effects of situational variables and starting quarter score in the outcome of elite women's water polo game quarters. International Journal of Performance Analysis in Sport, 14 (1), 73-83. doi:10.1080/24748668.2014.11868704

Gómez, M., Lago-Peñas, C., \& Pollard, R. (2013). Situational variables. In T. McGarry, P. O'Donoghue, \& J. Sampaio (Eds.), The Routledge handbook of sports performance analysis (pp. 259-269). London: Routledge International Handbooks.

Gómez, M., Lorenzo, A., Ibañez, S., \& Sampaio, J. (2013). Ball possession effectiveness in men's and women's elite basketball according to situational variables in different game periods. Journal of Sports Sciences, 31(14), 1578-1587. doi:10.1080/02640414.2013.792942

Gómez, M., Méndez, C., Indaburu, A., \& Travassos, B. (2018). Goal effectiveness after players' dismissals in professional futsal teams. Journal of Sports Sciences, 37(8), 857-863. doi:10.1080/02640414.2018.1531498

Gómez, M., Moral, J., \& Lago-Peñas, C. (2015). Multivariate analysis of ball possessions effectiveness in elite futsal. Journal of Sports Sciences, 33(20), 2173-2181. doi:10.1080/02640414.2015.1075168

Göral, K. (2018). Analysis of Serbia UEFA Futsal Euro 2016 competitions in terms of some variables. Journal of Education and Training Studies, 6(10), 1-6.

Lago-Ballesteros, J., Lago-Peñas, C., Rey, E., Martínez, L., \& Domínguez, E. (2012). El éxito ofensivo en el fútbol de élite: Influencia de los modelos tácticos empleados y de las variables situacionales. European Journal of Human Movement, 1(28), 145-170.

Lago-Peñas, C. (2009). The influence of match location, quality of opposition, and match status on possession strategies in professional association football. Journal of Sports Sciences, 27(13), 1463-1469. doi:10.1080/ 02640410903131681

Maneiro, R., Casal, C., Ardá, A., \& Losada, J. (2019). Application of multivariant decision tree technique in high performance football: The female and male corner kick. PloS One, 14(3), e0212549. doi: 10.1371/journal.pone.0212549

Méndez, C. (2018). Rentabilidad del portero jugador de futsal, y la conveniencia de su entrenamiento desde las etapas de formación. Revista Pedagógica De Educación Física ADAL, 21(36), 34-39.
Méndez, C., Gómez, M., Rúiz, L., \& Travassos, B. (2019). Goalkeeper as an outfield player: Shooting chances at critical moments in elite futsal. International Journal of Performance Analysis in Sport, 19(2), 179-191. doi:10.1080/ 24748668.2019.1581967

Méndez, C., Gómez-Ruano, M., Ruiz, L., \& Cui, Y. (2017). Unfavorable critical moments and way of facing them from the futsal coach's point of view through ad hoc questionnaire. RICYDE. Revista Internacional de Ciencias del Deporte, 13(50), 331-355. doi: 10.5232/ricyde2017.05002

Mendez, C., Gonçalves, B., Santos, J., Ribeiro, J., \& Travassos, B. (2019). Attacking profiles of the best ranked teams from elite futsal leagues. Frontiers in Psychology, 10, 1370. doi: 10.3389/fpsyg.2019.01370

Méndez, C., \& Méndez, V. (2005). Madrid Patent No. 2.622.587. O. E. d. P. y. Marcas.

Miloski, B., Pinho, J., Gobo, C., Rebouças, P., \& Schultz, A. (2014). Quais ações técnico-táticas realizadas durante as partidas de futsal podem discriminar o resultado de vitória ou derrota? Revista Brasileira De Educação Física E Esporte, 28(2), 203-209.

Moore, R., Bullough, S., Goldsmith, S., \& Edmondson, L. (2014). A systematic review of futsal literature. American Journal of Sports Science and Medicine, 2 (3), 108-116. doi: 10.12691/ajssm-2-3-8

Navarro, R., Gómez, M., Lorenzo, J., \& Jiménez, S. (2013). Qualitative analysis of critical moments in basketball. Revista de Psicología del Deporte, 22(1), 249-251.

Navarro, R., Lorenzo, A., Gómez, M., \& Sampaio, J. (2009). Analysis of critical moments in the league ACB 2007-08. Revista de Psicología del Deporte, 18(3), 391-395.

Newton-Ribeiro, F. (2011). A influência do goleiro linha no resultado do jogo de futsal. RBFF-Revista Brasileira De Futsal E Futebol, 3(9), 187-198.

Paz-Franco, A., Bores-Cerezal, A., Barcala-Furelos, R., \& Mecias-Calvo, M. (2014). Analysis of the conducts of elite futsal goalkeeper in the different situations of the game. American Journal of Sports Science and Medicine, 2(3), 71-76. doi: 10.12691/ajssm-2-3-1

Pereira-Guimarães, P., Neves, J., Rodrigues, E., \& Coppi, A. (2010). O número de faltas não teve influência no resultado do mundial de futsal de 2008. RBFFRevista Brasileira De Futsal E Futebol, 2(5), 116-121.

Poffo, I., \& Lima, E. (2012). Análise dos gols na primeira fase da liga de futsal 2012. RBFF-Revista Brasileira De Futsal E Futebol, 4(12), 118-123.

Robinson, G., \& O'Donoghue, P. (2007). A weighted kappa statistic for reliability testing in performance analysis of sport. International Journal of Performance Analysis in Sport, 7(1), 12-19. doi: 10.1080/24748668.2007.11868383

Sampaio, J., Lorenzo, A., \& Ribeiro, C. (2006). Momentos críticos en los partidos de baloncesto: Metodología para identificación y análisis de los acontecimientos precedentes. Cultura, ciencia y deporte: revista de ciencias de la actividad física y del deporte. Universidad Católica de San Antonio, 2(5), 83-88.

Sampedro, J., \& Prieto, J. (2011). La territorialidad como factor asociado a la ventaja de jugar en casa. Un estudio comparativo por regiones en la liga de fútbol y en la liga de fútbol sala de España. European Journal of Human Movement, 1(26), 93-104.

Sampedro, J., \& Prieto, J. (2012). El efecto de marcar primero y la ventaja de jugar en casa en la liga de fútbol y en la liga de fútbol sala de España. Revista de Psicología del Deporte, 21(2), 301-308.

Schnell, A., Mayer, J., Diehl, K., Zipfel, S., \& Thiel, A. (2014). Giving everything for athletic success!-Sports-specific risk acceptance of elite adolescent athletes. Psychology of Sport and Exercise, 15(2), 165-172. doi: 10.1016/j. psychsport.2013.10.012

Siqueira, O., Da-Silva, M., Aragonez, V., Damico, J., \& Crescente, L. (2016). O tempo de incidência dos gols em equipes de diferentes níveis competitivos da liga nacional de futsal. Revista Brasileira De Ciências Do Esporte, 36(2), 789-801.

Travassos, B., Araújo, D., Vilar, L., \& McGarry, T. (2011). Interpersonal coordination and ball dynamics in futsal (indoor football). Human Movement Science, 30 (6), 1245-1259. doi: 10.1016/j.humov.2011.04.003

Vicente-Vila, P. (2012). La influencia del portero-jugador en la eficacia ofensiva de un equipo de fútbol sala. Futbolpf: Revista De Preparacion Física En El Futbol, 1 (5), 29-43.

Vicente-Vila, P., \& Lago-Peñas, C. (2016). The goalkeeper influence on ball possession effectiveness in futsal. Journal of Human Kinetics, 51(1), 217-224. doi: 10.1515/hukin-2015-0185

Viera, A., \& Garrett, J. (2005). Understanding interobserver agreement: The kappa statistic. Family Medicine, 37(5), 360-363.

Volker, M. (2006). Reporting effect size estimates in school psychology research. Psychology in the Schools, 43(6), 653-672. doi: 10.1002/ pits. 20176 